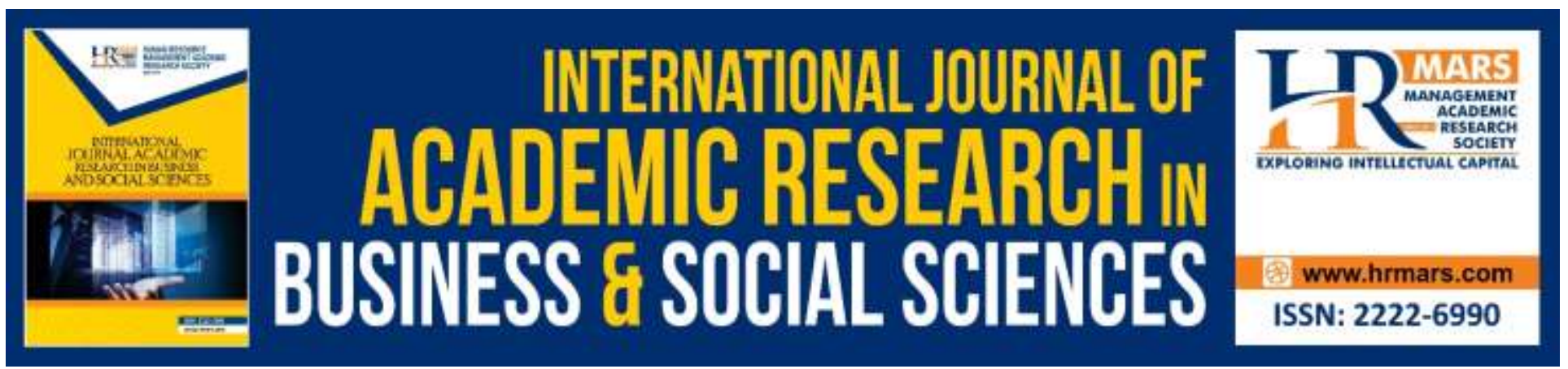

\title{
Assessment of IMF Deregulation and Liberalization of Trade and Persistence Crises of Development in Nigeria from 2000- 2018
}

Raziqa Muhammad Shafiu and Mohd Afandi Salleh

To Link this Article: http://dx.doi.org/10.6007/IJARBSS/v10-i6/7263

DOI:10.6007/IJARBSS/v10-i6/7263

Received: 04 April 2020, Revised: 18 May 2020, Accepted: 26 May 2020

Published Online: 08 June 2020

In-Text Citation: (Shafiu \& Salleh, 2020)

To Cite this Article: Shafiu, R. M., \& Salleh, M. A. (2020). Assessment of IMF Deregulation and Liberalization of Trade and Persistance Crises of Development in Nigeria from 2000-2018. International Journal of Academic Research in Business and Social Sciences, 10(6), 88-103.

Copyright: (c) 2020 The Author(s)

Published by Human Resource Management Academic Research Society (www.hrmars.com)

This article is published under the Creative Commons Attribution (CC BY 4.0) license. Anyone may reproduce, distribute, translate and create derivative works of this article (for both commercial and non-commercial purposes), subject to full attribution to the original publication and authors. The full terms of this license may be seen

at: http://creativecommons.org/licences/by/4.0/legalcode

Vol. 10, No. 6, 2020, Pg. 88 - 103

Full Terms \& Conditions of access and use can be found at http://hrmars.com/index.php/pages/detail/publication-ethics 


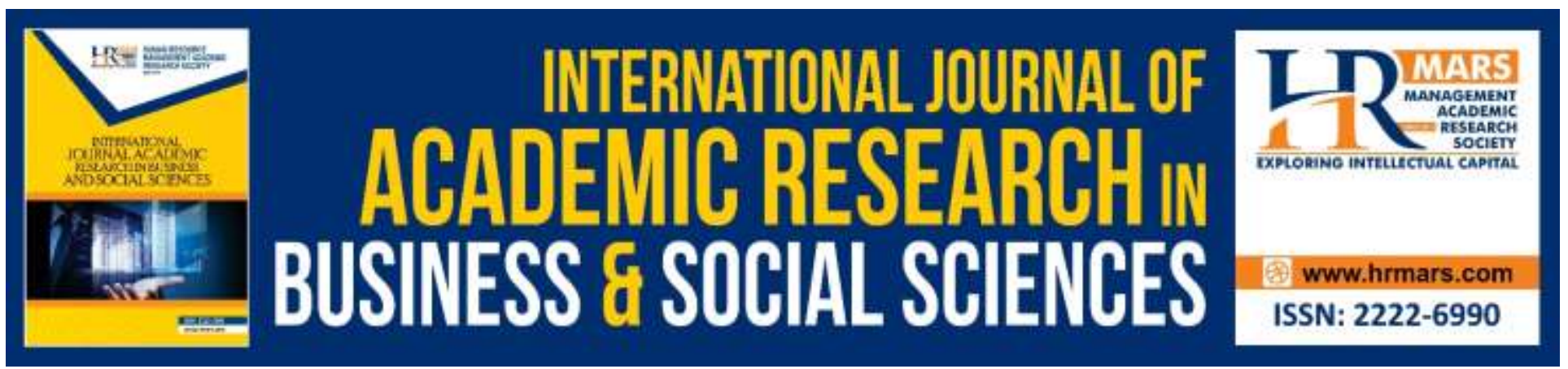

\title{
Assessment of IMF Deregulation and Liberalization of Trade and Persistence Crises of Development in Nigeria from 2000-2018
}

\author{
Raziqa Muhammad Shafiu and Mohd Afandi Salleh \\ Faculty of Law and International Relations, Universiti Sultan Zainal Abidin (UniSZA), Terengganu, \\ Malaysia. \\ Email: raziqashafiu@ymail.com
}

\begin{abstract}
The ongoing development crisis that engulfed the post-colonial Nigerian state in the context of externally and internally oriented policy prescriptions, coupled with abundant natural and human resources within its territory, has continued to elicit disputes among scholars and policy makers. With the transition from a military to a democratically elected government in 1999, then President Olusegun Obasanjo, through the instrumentality of the IMF-sponsored National Economic Empowerment and Development Strategies (NEEDS), adopted and implemented, among other things, the reforms of deregulation and trade liberalization that have been proclaimed a panacea for resolving the development crisis in the country. It is in this connection that our study was saddled with the responsibility of interrogating the nexus between the adoption and subsequent implementation of the IMF-induced reforms and the persistent development crises in Nigeria in the context of ascertaining whether the adoption of IMF-imposed deregulation policy reduced the Human Development Index in Nigeria; and whether the implementation of IMF policy of liberalization of trade increased the unemployment rate in Nigeria between 2000 and 2018. With the support of the Mixed Economic Structural and Economic Nationalism Analytical Approaches, combined with the qualitative descriptive method of data analysis and the documentary method of data collection, the study argued that the deregulation and trade liberalization reforms were responsible for the decline in $\mathrm{HDI}$ and the increase in the unemployment rate. From this point of view, the paper recommended the implementation of a two-phase development plan and the use of a regional integration development strategy as practical solutions to Nigeria's persistent development challenges.

Keywords: Human Development Index, Needs, Deregulation, Trade Liberalization, Economic Nationalism, Development Crisis.
\end{abstract}

\section{Introduction}

Nigeria is endowed with an abundance of oil, minerals, human and natural resources, rendering it the biggest economy in Africa. Nigeria has been considered as a middle-income country 
INTERNATIONAL JOURNAL OF ACADEMIC RESEARCH IN BUSINESS AND SOCIAL SCIENCES Vol. 10, No. 6, June, 2020, E-ISSN: 2222-6990 @ 2020 HRMARS

with mixed economy. Similarly, the country has being identified as one of the evolving marketing in the world with developing manufacturing, enhanced financial services, communication, entertainment sectors and technology aspects. In terms of nominal GDP 2018, the country is ranked as the $27^{\text {th }}$ largest economy in the world while it is the largest in Africa (Olabisi, et al., 2019). It has been focused mainly on the petroleum industry since the early 1960s. However, rampant corruption, weak governments because of poor governance, and political turmoil have kept the citizens from enjoying the country's economic buoyancy (Ukpe \& Omeonyekwule, 2019). Transparency International published the Corruption Perception Index of 180 nations in 2017. Nigeria was ranked 148th from the lowest eligible to the most competitive country in the report. (Transparency International, 2017). As a result, the country's human security and growth indices were not impressive (Dauda, 2017).

A series of world oil price increases from 1973 generated fast economic growth in services such as transportation, construction, production and government (S. Dauda, 2019). This led to a large influx of rural individuals into the bigger urban centers, agricultural production stagnated to such an extent that cash crops such as palm oil, peanuts (groundnuts) and cotton no longer constituted important export commodities (Olabisi, et al., 2019). Moreover, since about 1975, for domestic consumption, Nigeria was compelled to import such fundamental commodities as rice and cassava. This system worked well if oil revenues remained constant, but since the late 1970s the agricultural sector has been in continuous crisis due to the fluctuating world oil market and the country's rapid population growth (Dauda, 2019).

Although a large part of the population remained engaged in farming, too little food was produced, requiring increasingly costly imports. By restricting agricultural imports and concentrating, albeit shortly, on multiple agricultural and indigenization plans, the various governments (most of them military-run) have addressed this problem (Akaakar, 2019). The state started to privatize many state-run enterprises in the early 1990s especially in telecom, energy, and transportation - to improve service performance and decrease public reliance. By the beginning of the 21st century, most businesses had been successfully privatized, but a few remained in government hands (Ebinumo \& Ikunga, 2019).

Most of the Nigerian population is living in extreme poverty which was the reason why Nigeria see the need to seek for assistance from the developed economies and the International organizations (Dauda, 2017). Therefore, the IMF terms with Nigerian government on the agreement for Nigeria to devalue its currency to $33 \%$, subsidy removal of $60 \%$ from petroleum, privatization of public enterprise, cutting public expenditure and liberalization of the trade. As at then, the Nigerian government felt the removal of subsidy from petroleum were politically unpalatable. Therefore, the then Nigerian government refuse to comply with that term, as the deterioration continue in the economic situation of the nation. The government therefore implemented the Structural Adjustment Program (SAP) (Igwe et al., 2016).

Furthermore, and worthy of mention is the New Partnership for Africa's Development (NEPAD) policy agenda of 2001 which sought to; bridge the continued unequal relationship between Africa and the developed economies, eradicate poverty, place African countries both individually and collectively on the path of sustainable growth and development, halt the marginalization of Africa in the globalization process. Unfortunately, these mouthwatering and so-called highly sophisticated policies could not transport Nigeria into an economically viable nation. The development crisis in 
INTERNATIONAL JOURNAL OF ACADEMIC RESEARCH IN BUSINESS AND SOCIAL SCIENCES

Vol. 10, No. 6, June, 2020, E-ISSN: 2222-6990 @ 2020 HRMARS

Nigeria has continued to defy all the necessary diagnoses or curative pills applied to salvage it (Okolie, 2015).

In 2003, Nigeria through the IMF-guided National Economic Empowerment and Development Strategy (NEEDS) strengthened effort on market-oriented reforms as a solution to the multifarious developmental challenges of the country. In view of the above, the study relying on documentary method of data collection together with the qualitative/descriptive method of data analysis, examined the nexus between the adoption and implementation of IMF reforms of deregulation/trade liberalization and the persistent crises of development in Nigeria from 2000 to 2018 . Essentially, the study investigated the role of deregulation and trade liberalization reforms of the International Monetary Fund in deepening the Human Development Index and unemployment crisis in Nigeria. Also, attempts were made to provide alternative viewpoints that would salvage the identified problems.

\section{Problem Identification}

Despite efforts grew in the past to tame the tide of underdevelopment, the post-colonial Nigerian state has continued to be enmeshed in development crisis. Available statistics from the Debt Management Office, Central Bank of Nigeria and National Bureau of Statistics indicate that the country is plunged into deep economic crisis. For instance, the information released by the Debt Management Office shows that while the total debt profile of Nigeria stood at 3.1 billion dollars in 2007 , it has risen dramatically to an astronomical level of $\$ 5.3$ billion in 2014 . Similarly, the official reports of the Central Bank of Nigeria indicate that the inflation rate has progressed from $6.9 \%$ in $2000,18.9 \%$ in $2001,14 \%$ in 2003, 11.6\% in 2008 and $13.7 \%$ in 2010.

In the same vein, data generated from the National Bureau of Statistics shows that unemployment and poverty rates have witnessed unimaginable growth within the period of the study. As a result, Deaton (2005) posited that the Sub-Saharan Africa, which Nigeria is part of, is the only region in the world where the proportion of the poor has been rising over time and where the poor are relatively worse off than their counterparts in other parts of the world. In the same vein, Sesrtcic (2007) observed that the development challenges facing sub-Saharan Africa can be described by variety of poverty and inequality measures through time or in comparison with other nations or regions of the world. He pointed that on the average, 45 percent of the Sub-Saharan Africa's 726 million people live below the international poverty line of US 1 dollar a day (http://www.sesrtcic.org/files/article/233.pdf).

\section{Objectives}

- To examine the nexus between the adoption and implementation of IMF reforms of deregulation/trade liberalization and the persistent crises of development in Nigeria from 2000 to 2018.

- To investigate the role of deregulation and trade liberalization reforms of the International Monetary Fund in deepening the Human Development Index and unemployment crisis in Nigeria.

- To provide alternative viewpoints that would salvage the identified problems. 


\section{Methodology}

This research work adopted secondary type of data. The type of data collection anchored on sourcing its information from review of relevant textbooks, internet materials, periodic publications, newspaper, magazines, pamphlet, and journals on IMF and crisis of development in Nigeria are used in this research. Therefore, the method of data analysis is explanatory in nature.

- Sources of Data

Since the method of data is based on secondary source, the sources adopted for the collection of data will include relevant books, conference papers, unpublished works, interviews, journals and the internet.

- Methods of Data Collection

This study has adopted a variety of methods. These include research, use of the library materials, internet search, and the conduct of interviews.

- Technique of Data Analysis

Data analysis is based on the qualitative method, which is explanatory in nature. The descriptive parts will consist of explaining the relationship between the IMF and Nigeria as a peripheral economy. This would help in finding out the degree of effectiveness of IMF's deregulation and liberalization of trade towards socio-economic development of Nigeria.

\section{Literature Review}

Scholarly contributions in relation to the continuous crisis of development in Nigeria have been viewed from two eyeglasses. Some scholars like Ake (1981), Galtung (1971), Nnoli (1981), Onimode (1983), Chossudovsky (1997), Rodney (1972), Offiong (1980), and Okolie (2005 \& 2015) blamed the underdevelopment in the peripheral socio-economic formations on certain exogenous factors like imperialism and neo-imperialism, others like Rostow (1960), Hoselitz (1960), Bernstein (1971), argued that the protracted nature of Africa's underdevelopment lies in endogenous factors innate in the region which among other things, inhibited the continent from transiting from traditionalism to modernism.

However, the first group of scholars argued that the cause of development crisis is integral in the nature and character of the capitalist economic system which slightly divided the world into two namely, the primary producers of goods and the industrial producers of goods. Here, the developing states were tactically assigned the role of producer of primary commodity, which consistently reduced their share and influence in the international system while the industrialized nations of the world were assigned the role of transforming the raw materials into finished or consumable goods, thereby giving them excessive control and dominance in the international system. The developed economies state their dominance through Breton-Wood Institutions whose major occupation is to initiate practices and prescribe policies that will give them the leverage to sustain and perpetuate their dominance of the developed economies in the international system. Okolie (2015) specifically argued that the practices and policy prescriptions have of the Breton-Wood Institutions remains the root causes of the underdevelopment in the peripheral formation.

On the other hand, the second group of scholars believed that the causes of underdevelopment in Africa are rooted in certain endogenous factors intrinsic in the continent that inhibit economic development. They contended that the inability of Africa to imitate the development trajectories and patterns of the developed economies makes it impossible for them to achieve genuine development. 
INTERNATIONAL JOURNAL OF ACADEMIC RESEARCH IN BUSINESS AND SOCIAL SCIENCES Vol. 10, No. 6, June, 2020, E-ISSN: 2222-6990 @ 2020 HRMARS

Contemporary scholars and policy makers like Achebe (1983), Ikejiani (2008) and Nnamani (2003), beyond the views held by the foregoing scholars, implicated leadership failure, corruption, protracted military rule, ethnicity and changed federal structure as fundamental catalysts that fueled and sustained underdevelopment crisis in Nigeria. They insisted that sincere leadership is the key to solving the developmental problems of Nigeria. Equally, scholars like Ibe (2010), Nwokocha (2007) saw inadequate planning as a major factor inhibiting the development of Nigeria. Moreover, Obadan (2014) noted that lack of targeting mechanism for the poor, political and policy instability, inadequate coordination of various policies, stark budgetary, management and governance problems, lack of accountability and transparency, lack of mechanism for sustainability, inappropriate programme design, among numerous others, were responsible for the crises of development in Nigeria. At this juncture, it is pertinent to state that the causes of underdevelopment in Nigeria as demonstrated by the foregoing scholars cannot be meaningful without recourse to its root. Here, we argued that it is the structure of colonialism and by extension, imperialism which breeds ineffective leadership and weak state institutions that are responsible for the manifestations of indicators of underdevelopment in Nigeria.

As a corollary of the above, the development crisis of Nigeria cannot be fully comprehended or explained without recourse to the history and impact of imperialism and neo-imperialism, which among other things, not only facilitated, but equally sustained the integration of the country into the global capitalist socio-economic formation and succeeded in distorting and disarticulating the economy. This view was collaborated and shared by Osman (1994) when he insisted that: "the subordination of African countries into specialist raw material satellites to serve western interests in the post-independence period was carried out by northern governments in conjunction with several multilateral organizations. Spearheading this organization are the World Bank and IMF. Behind them are others such as the Group of Seven, the Paris Club and the London Club and a host of giant banks and multinational companies".

Historically, Nigeria was once a cheerful economy before the 1980s that it became attractive to so many nationals who sought means of livelihood in it. In this period, Nigeria's GDP stood at $132 \%$ in the 1960 s reaching a prime growth of $283 \%$ in the 1970 s. Suddenly, once prosperous economy was laid prostrate with comatose economy with a highly impoverished people as the GDP shrank from $283 \%$ in the 1970 s to $66 \%$ in the 1980 s (https://en.m.wikipedia.org/wiki/economy of Nigeria). The prolonged economic crisis made Nigeria sought for financial and technical aid from the IFIs. As we know, the aids of the IFIs are always packaged with conditionality in the form of Structural Adjustment Program. The SAP which was foisted as a therapeutic prescription for the healing of ailing Nigerian economy worsened the already destabilized economy.

As seen above, several researchers have studied and identified various factors that accounted for the relentless predicaments of development in Nigeria. However, none of these studies appeared to have interrogated the link between the adoption of the International Monetary Fund reforms and the intensification of crisis of development in Nigeria between 2000 and 2018, hence creating gap in the academic community. It is on the basis of the foregoing that this study sought to ascertain whether the adoption of IMF imposed deregulation policy reduced the Human Development Index in Nigeria; and the implementation of IMF policy of liberalization of Trade increased the unemployment rate in Nigeria between 2000 and 2018. 
INTERNATIONAL JOURNAL OF ACADEMIC RESEARCH IN BUSINESS AND SOCIAL SCIENCES Vol. 10, No. 6, June, 2020, E-ISSN: 2222-6990 @ 2020 HRMARS

\section{Theoretical Framework}

Existing studies that examined the dynamics of development crisis in the peripheral socio-economic formation arising from the asymmetrical relationship between the developed and developing societies have always relied on the theoretical postulations of dependency paradigm, developed by the neo-Marxist scholars. However, a critique on the analytical strength of the dependency approach has shown that it is riddled with fundamental inadequacies which rendered it powerless to continue serving as a suitable tool of analysis for contemporary and related issues in the international political economy. As a result, the study adopted the blended economic structuralism and economic nationalism theories.

Economic nationalism and economic structuralism were popularized in Gilpin (1987), Pettman (1986) and Balaam and Veseth (1996). According to the core proponents, economic nationalism is based on the realist positions that conflict characterize the international economic relation and that the international system is a zero-sum game where the gain of a player is automatically the loss of the other player. It is also anchored on the assumption that the states or international institutions like the International Monetary Fund should use their economic strength to further their interest.

To actualize these motives, the proponents outlined the three economic practices or strategies namely: imperialism and neo-imperialism, economic incentives and disincentives, and protectionism and domestic economic support. Imperialism and neo-imperialism connote the direct or indirect domination of foreign lands for national economic gain which may be facilitated by establishment of colonial rules or through the activities of the transactional and multinational corporations. It was this idea that propelled Europeans outward movement to conquer the great empires and dominated so much of the world until recent decade. In the same vein, the foreign corporations operating in the satellite worlds are also in the pursuit of same objectives.

On the other hand, economic incentives entail the use of carrot approach like favorable trade policies and foreign aid to advance economic objective of a state while disincentives means the use of stick approach like sanctions and high tariffs to promote the economic interest of the advanced capitalist societies. Meanwhile, protectionism and domestic support refers to the third set of idea propagated by the economic nationalists wherein they express suspicion that economic interdependence undermines state sovereignty and weakens national economic strength. As a result, the economic nationalists would prefer that the developed societies should use trade barriers, economic subsidies and other protectionist policies to shield and further their national interest.

In other to buttress their viewpoints, the economic nationalists employed the lifeboat analogy to rationalize the above outlined strategies. According to the theorists, the image depicts the world as a lifeboat that can support only few passengers. The people of the Economically Developed Countries (EDCs) are in a boat while the billions of the Less Developed Countries (LDCS) are in the sea in the peril of drowning and clamoring to get aboard (Gilpin, 1987). The theorists contended that the lifeboat is incapable of saving the lives of the people who are at the risk of drowning in the sea, therefore, if everyone gets in the lifeboat, it will sink. The logic behind this argument is that if the EDCs offer genuine economic assistance to the LDCs, it will jeopardize the existence of the former, hence, the need to exploit and make the LDCs perpetually dependent and appendage of the EDCs.

On the other hand, economic structuralism assumes that the conduct of the world is organized economically. Economic structuralists contend that the global system is systematically divided into the metropolitan and satellites states and that the former works to keep the latter weak and poor in order to exploit them. Within the economic structuralism theory exist two approaches 
namely: the Marxist and dependency approach. While the Marxist theorists maintain that history proceed by means of a historical dialectics or clash of the opposing ideas with a resultant new order, the dependency theorists otherwise referred to as the neo-Marxists, argued that the exploitation of the LDCs by the EDCs is exercised through the imperialism and it is driven by the EDCs need for primary resources, external markets, profitable investment opportunities and low wage labor. They however maintained that the dependence of the LDCs is maintained in number of ways such as structuring the rules and practices of the international economics to benefit the North.

In applying the theory to our study, the theories are germane in understanding the dynamics and concomitant effects of the interactions and relations between the International Monetary Fund (an institution of the developed nations) and the developing states, which Nigeria is part of. Firstly, the views expressed by the theorists of the two paradigmatic schools is very significant in appreciating the hidden rationale behind the creation of the International Monetary Fund as a mere tool of the metropolitan states in foisting and perpetuating their dominance in the international system. This dependence nay asymmetrical relationship between the two poles is maintained based on the wide held notions by the metropolitan states that any genuine developmental assistance to the satellite states will jeopardize the economic interest of the former.

Secondly, the theories help us to understand that the technical assistance or economic carrot emanating from the International Monetary Fund has been designed to deepen the developmental crises in the developing countries so that the developed nations will continue to dictate the rule game in the international political economy. This is done through the imposition of unfavorable policies like devaluation, privatization, deregulation, liberalization of trade as yardstick for assessing loans and foreign grants. Meanwhile, the economic disincentive measure is always applied to any recalcitrant state that failed to toe the development paradigms of the economically developed states. Thirdly, it is the contention of this theoretical framework that the foreign aids of the International Financial Institutions only function to preserve and sustain the dependence and integration of Nigeria into the world capitalist system. The more Nigeria borrow from the International Monetary Fund, the more debts increases and no matter how much they try, they are still dependent on the West because of their incapacity to pay their debts which ultimately leads to development crisis.

Furthermore, the theory challenges us to understand that the International Monetary Fund does not operate in vacuum. They function in connivance with the local elites or preferably, surrogates who were compensated with personal wealth in return for governing their countries in line with their dictates. On the way forward, the theory believes that an internally generated policy will be fundamental in developing the production forces to make the Nigerian economy viable for global participation and competition.

\section{Conceptual Clarifications \\ Conceptualizing Deregulation}

Deregulation is one of the economic prescriptions preserved in the Washington Consensus, and a major conditionality for accessing loans from the International Financial Institutions like the International Monetary Fund and World Bank. Over the years, African scholarship has been grappling with the challenge of assigning a suitable definition to the concept of deregulation. The situation was basically influenced by three developments. Firstly, there has been a tendency by scholars to assign peripheral or superficial meaning to the concept of deregulation. In this case, they attempt to define deregulation by using terms like deregulate, decontrol or rather state that deregulation is the direct 
antonym of regulation (Ojo, 2010; Wikipedia, 2011). Secondly, others have avoided the usage of the term and rather prefer to employ privatization and liberalization to denote deregulation. Thirdly and lastly, scholars have used deregulation and privatization interchangeably (Dappa \& Daminabo, 2011; Kalejaiye et al., 2013).

However, scholars like Olashore (1991), Winston (1993), Bannock et al., (1999), Adegbemile (2007), Ajayi \& Ekundayo (2008), Owojori (2011), Eme \& Onwuka (2011), Kuye (2012) provided the framework for distinguishing deregulation from the concept of privatization.

To us, deregulation is a crucial aspect towards the liberalization of an economy. Deregulation is a systematic and deliberate activity wherein government through legislation withdraws its regulatory role of determining what is to be produced, when it is produced, how it is to be produced and how it is distributed in the state, thereby allowing the forces of demand and supply to play this vital role in an economy. Deregulation has to do with the whole gamut of policies that deal with the removal of government controls or restrictions either in one sector or all the sectors of an economy.

The sectors of an economy include financial, transportation, communication, energy, utilities etc. Deregulation generally takes place either at the sectoral or multi-sectoral level. For instance, the transportation sectors of an economy consist of rail, land and air while the financial sectors of an economy are banking and insurance. Meanwhile, the transfer of government asset to private individual for management and control which is done at sub-sector level connotes privatization.

This brings us to the distinguishing and fundamental difference between deregulation and privatization. While deregulation takes place at sectoral level, privatization is an activity that takes place at sub-sector segment of an economy. Privatization can only take place in a deregulated economy. Deregulation opens door for privatization; hence, without deregulation, there cannot be privatization. From the analysis, we have established the interconnectivity between deregulation and privatization with minor differences that exist between the two.

\section{Conceptualizing Trade Liberalization}

Liberalization of Trade or Trade Openness has been at the center of the discussion of development policy in recent time (Tung, 2015). Trade liberalization, which is sometimes associated with concepts like trade openness, free trade, laissez faire, economic liberalism among others sharply contrast with mercantilism, economic nationalism or protectionism. While the former advocates for unregulated and uninterrupted movement of goods and services within the global system, the latter strongly argue for the application of restrictive measures to limit free flow of trades between States.

Wide ranges of definitions have been given to the concept of trade liberalization. For instance, Investopedia conceptualized trade liberalization as the removal or reduction of restrictions or barriers on the free exchange of goods between nations. This includes the removal or reduction of both tariff (duties and surcharges) and nontariff obstacles like licensing rules, quotas and other requirements (http://www.investopedia.com/terms/t/tradeliberalization.asp\#ixzz3zl25eQDI).

Similarly, trade liberalization is seen as the removal of or reduction in the trade practices that thwart free flow of goods and services from one nation to another. It includes dismantling of tariff (such as duties, surcharges, and export subsidies) as well as nontariff barriers (such as licensing regulations, quotas, and arbitrary standards)

(http://www.businessdictionary.com/definition/tradeliberalization.html\#ixzz3zl8J6CNb). 
INTERNATIONAL JOURNAL OF ACADEMIC RESEARCH IN BUSINESS AND SOCIAL SCIENCES Vol. 10, No. 6, June, 2020, E-ISSN: 2222-6990 @ 2020 HRMARS

\section{Conceptualizing Human Development Index}

The Human Development Index (HDI) is an annual index published by the United Nation Development Program.

\section{Unemployment}

Conceptually, unemployment connotes a situation in which people who are eminently qualified based on age, educational standard and willing to work are unable to find work at a prevailing wage (ILO, 1982; Gbosi, 1997). Stressing further, World Bank (1998) observed that the unemployed is a member of an economically active population, who are without work but available and seeking, including people who have lost their jobs and those who voluntarily left work.

Arising from the above elucidation is the fact that every population of a country is divided into two categories: the economically active and the economically inactive. The economically active refers to the labor force or better still, the working population who are willing and able to work, including those actively engaged in the production of goods and services (employed) and those who are unemployed.

While, unemployed refers to people who are willing and capable of work but are unable to find suitable paid employment. However, the economically inactive refers to people who are neither working nor looking for jobs. Examples are the housewives, full time students and those below the legal age for work, old and retired persons. The unemployment rate can be expressed as a percentage of the total number of persons available for employment at any given time. Thus:

Unemployment rate $=$ Unemployed Workers/Total Workers

\section{IMF-Nigeria Relations in Review}

Since Nigeria become independent, the country has continued to embark on economic reforms which were normally influenced by the prevailing economic situation and circumstance. The two contending approaches (economic nationalism and economic liberalism) have always provided the ideological underpinning, basis, guideline and direction for the structural transformation of Nigeria's economy at any time. In this context, we argue that the country has been guided by the philosophical disposition of either economic nationalism or economic liberalism. While economic nationalism favours government intervention and control of the economy, the economic liberalism espouses the marketization or liberalization of the economy.

At independence up till early 1970s, the country embraced economic nationalistic principles with agriculture as the mainstay of the economy. As noted by Dappa \& Daminabo (2011): "during this period, manufacturing and mining activities were at a very low level of development. The country's participation in the external trade was based on the level of economic activities in agriculture. Thus, agricultural commodities dominated the country's export trade while manufactured items dominated imports".

However, the boost in the economic revenue of Nigeria arising from the oil boom of 1973/74 altered the economic activities of the country as government channeled the burgeoning revenue to infrastructural, capital, human and public sector development. This era can best be described as the golden era of Nigeria (Ovaga, 2010).

Thus, the drastic decline in the revenue of Nigeria occasioned by the oil glut in the international market exposed the country to economic recession which nearly led to the collapse of her economy. This ugly development and the urgent need to address this situation culminated into 
the adoption of the neoliberal economic framework as articulated in the Washington and PostWashington Consensus and propagated by the International Financial Institutions. This was possible through the Stabilization Act of 1982, budget-tightening measure of 1984 and finally the Structural Adjustment Programme (SAP) of 1986. The infiltration of Nigeria's economy by the International Monetary led to the implementation of different policy reforms like removal of government subsidies, trade liberalization, deregulation and privatization of public enterprises among numerous others. The implementation of the policy reforms was among the conditionalities for accessing financial and technical assistance from the International Monetary.

With the return to democracy in 1999, the then President Obasanjo reverted to the neoliberal economic agenda cum prescriptions of IMF, which was subtly meant to give international credibility and acceptance to his authoritarian government. The neo-liberal prescriptions were articulated under the blueprint of the National Economic Empowerment Development Strategy (NEEDS). The National Economic Empowerment Development Strategy is a coherent strategic framework designed to usher Nigeria into the path of sustainable economic development through the pursuit of market-oriented reforms. From 1999 till date, Nigeria's economic path has been under the tutelage and direction of the IMF.

\section{New Phase of IMF Reforms in Nigeria, 1999-2018}

Undoubtedly, the historical antecedence of IMF reforms in Nigeria can be traced to the Babangida regime of 1980s when the administration adopted and implemented the Structural Adjustment Programme. However, the emergence of a democratically elected government of the then President Olusegun Obasanjo in 1999 opened a new phase in the IMF-Nigeria relation. This new relation facilitated the implementations of various neo-economic liberal policies of the International Monetary Fund, which was coordinated under through the National Economic Empowerment and Development Strategy (NEEDS) agenda (Okonkwo, 2014).

The NEEDS according to the initiators represent a sound and home grown development strategy saddled with the responsibility of achieving four cardinal objectives which are: wealth creation, employment generation, poverty reduction and value re-orientation through reform of government institution, development of the public sector, implementation of social charter etc. (NEEDS, 2004). However, the key elements of public sector development in the NEEDS strategy include the renewed privatization, de-regulation and trade liberalization programme which were basically designed to deemphasize the role of the state in the economic activities of the country and rather allow the forces of demand and supply to play this pivotal role (NEEDS, 2003).

However, to us, NEEDS framework is deliberate agenda of the Metropolitans to foist and extend their capitalist ideology on Nigeria. NEEDS development strategy is another edition of the failed Structural Adjustment Programme and a new form of Western imperialism designed to perpetuate their dominance and distort the economic development of Nigeria.

\section{Policy and Human Development Index in Nigeria}

In order to accord legitimacy and effectively without the usual altercation been exhibited by the media, pressure groups and civil society organizations; the respective governments in power drafted bills and submitted to the National Assembly. The Bills which were subsequently passed into laws, formed the basis for the institutionalization of deregulation reforms in Nigeria. The Public Enterprise Act 1999 CAP. P38 L.F.N. 2004, Telecommunication Act No. 19 of 2003 CAP No.23 L.F.N. 2004 and 
INTERNATIONAL JOURNAL OF ACADEMIC RESEARCH IN BUSINESS AND SOCIAL SCIENCES Vol. 10, No. 6, June, 2020, E-ISSN: 2222-6990 @ 2020 HRMARS

Electric Power Sector Reform Act, No. 6 of 2005 were among the extant laws that gave impetus to the adoption and implementation of deregulation policy in the telecommunication and power sectors of Nigeria economy.

Clearly, the core proponents of deregulation reform have argued and maintained that a deregulated economy has the capacity to: improve services, eradicate misuse of monopoly powers, attract local \& foreign investment, encourage innovation and introduce advanced services, generate government revenues, increase sector efficiency through competition and extend services to underserved and unserved areas (Ndukwe, 2005). The whole essence of the deregulation process as maintained by the apologists is the enhancement and sustainability of economic growth and development in a state.

However, available data of the Nigerian economy in the post-deregulation reforms in power and telecommunication sectors indicated relative success in certain areas while others recorded abysmal failure. For instance, the post-deregulation survey showed that the telecom's contribution to Nigeria's GDP rose from $0.62 \%$ in 2001 to $8.38 \%$ in 2014 while Nigeria's subscribers/tele density increased from 400,000 in 1999 to 139, 143, 610 in 2014. Also, the number of Nigerians employed in the telecom sector increased from 8,045 in 2011 to 8,449 in 2014 (NCC, 2014; NBS, 2015). On the other hand, minimal result was recorded in the power sector reforms as the 10,000 megawatts targeted in the process was not realized. Available statistics indicate that the number of megawatts generated in the post-power sector reform increased from 2,226 in 2005 to 3,800 in 2008 through a decline of 2,900 was observed in 2009 while it stood at 3,666.76 in 2014 (Federal Ministry of Power, 2014; NBS, 2015).

However, between 2000 and 2014, the national unemployment of Nigeria experienced significant growth amidst the implementation of trade liberalization policy of the International Monetary which, among other things, promised to generate job through massive trade flow, industrialization and foreign direct investment. Available statistics from the National Bureau of Statistics revealed that unemployment rate which stood at about $13.1 \%$ in the year 2000 , moved to $19.7 \%$ in 2009 and finally, to $26.2 \%$ in 2014 NBS (2012). Also, official reports indicated that each state of the federation is grappling with high rate of unemployment within the period under study. For instance, states like Bauchi, Adamawa, Gombe, Jigawa, Nasarawa, Niger, Yobe and Zamfara are occupying the apex positions in the unemployment ladder.

Accordingly, studies by Awogbenle and Iwuamadi (2010) and corroborated by Oduwale (2015) disclosed that out of 80 million youths representing about $60 \%$ of the total population, 64 million are unemployed while 1.6 million are underemployed. Furthermore, a cursory look at the international unemployment statistics showed that Nigeria remains crippled with massive unemployment rate. While the unemployment rates in countries like Algeria, Egypt, Liberia, Australia, Brazil, United Kingdom, Cuba, India, China and Ghana stood at about 10\%, 9.4\%, 3.6\%, 4.9\%, 6.5\%, 7.8\%, 1.6\%, $9.4 \%, 4.1 \%$, and $3.6 \%$ respectively; Nigeria's figure stood at $19.7 \%$, making it one of the highest in the world (Wikipedia, 2011).

Meanwhile, the collapse of the composite unemployment rate by level of education of the unemployed persons from 2004 to 2011 has shown that higher proportion of unemployment was recorded by secondary school leavers, followed by those who never attended school. On the other hand, the decomposition by age group indicated that those within the age bracket of 15-24 years has the highest percentage of unemployment while the age bracket of 60-64 years has minimal rate though all the groups witnessed steady growth between 2000 and 2014 . Similarly, the graduate 
unemployment rate presents a horrible picture as the trend moved from $25.6 \%$ in 2003 to $42.7 \%$ percent in 2011 according to official reports released by the National Bureau of Statistics in 2012. The implication of the foregoing illustrations and elaborations is that Nigeria's unemployment rate has increased consistently between 2000 and 2014. As a corollary of the above, we accept and authenticate our second hypothesis which states that the implementation of the IMF policy of trade liberalization accounted for increase in the unemployment rate in Nigeria within the period under study.

\section{Conclusion}

This study assessed the role of the International Monetary Fund in addressing the development crisis in Nigeria. In doing this, we interrogated the nexus between the implementation of the imposed policies of deregulation and trade liberalization with specific focus to ascertaining its effects on Human Development Index and unemployment situation in Nigeria. With available statistical data generated from official documents, the study associated the intensification of unemployment rate and decline in Human Development Index on the implementation of deregulation and trade liberalization reforms in Nigeria within the period under investigation.

The major findings of the study are: the adoption and implementation of deregulation policy has a negative impact on telecommunication and power sectors of the Nigerian economy; and, the implementation of the policy of trade liberalization has an adverse effect on Nigerian economy as it results to the increase in unemployment rate between the period under investigation. In this connection, we argued that the policy prescriptions of the International Monetary Fund are not the genuine medication for resolving the development crisis in Nigeria. Further, we argued that the integration of Nigeria into the global capitalist economic system through the impositions of various policies of IMF will continue to serve as impediment for achieving genuine development in the country, hence, the need for reappraisal.

As the country continue to search for a viable policy framework that will not only address the development challenges facing it, halt her sustained marginalization in the globalization process, as well as, increased her role and share in the global political economy, the study made the following suggestions. Firstly, we suggested that Nigeria should explore the opportunities that abound in the regional integration as an alternative strategy for realizing her development goals. Secondly, we recommended for the implementation of two-phased roadmap for development.

In phase one, emphasis will be placed on development of productive forces, reintroduction of Welfares programmes, industrialization, diversification of the revenue base and strengthening of state institution for optimum service delivery. In phase two however, with the realization of high level of productive forces and strong state institutions, the Nigerian state will now pursue liberalization reforms that will usher a competitive and consolidated economy.

\section{References}

Achebe, C. (1984). The trouble with Nigeria. Heinemann.

Adegbemile, A. A. (2007). Development of telecommunications in Nigeria and its impact on national development: Experience from around the world. Asian Journal of Information Technology, 6(8), 884-890.

Ajayi, I. A., \& Ekundayo, H. T. (2008). The deregulation of university education in Nigeria: Implications for quality assurance. Nebula, 5(4), 212-224. 
INTERNATIONAL JOURNAL OF ACADEMIC RESEARCH IN BUSINESS AND SOCIAL SCIENCES Vol. 10, No. 6, June, 2020, E-ISSN: 2222-6990 @ 2020 HRMARS

Akaakar, A. A. (2019). Oil dependency and national food security: A case for Nigeria.

Ake, C. (1981). A political economy of Africa (Vol. 4). London: Longman.

World Bank. Latin America, the Caribbean Region. Colombia, Ecuador, Venezuela Country Management Unit. Environmentally, \& Socially Sustainable Development Sector Management Unit. (1998). Project appraisal document on a proposed loan in the amount of US $\$ 5$ million to the government of Colombia for a peasant enterprise zones for peace project (No. 17991). World Bank.

Awogbenle, A. C., \& Iwuamadi, K. C. (2010). Youth unemployment: Entrepreneurship development programme as an intervention mechanism. African Journal of Business Management, 4(6), 831.

Veseth, M., \& Balaam, D. N. (Eds.). (1996). Readings in International Political Economy. Prentice-Hall. Bannock, G., Baxter, R. E., \& Rees, R. (1972). Penguin dictionary of economics.

Bernstein, H. (1971). Modernization theory and the sociological study of development. The Journal of Development Studies, 7(2), 141-160.

Chossudovsky, M. (1997). The Globalization of Poverty and III-health: Assessing the IMF-World Bank Structural Adjustment Program. In international conference Lighten the Burden of Third World Health, Cape Town.

Dao, A. T. (2015). Trade openness and economic growth. The Park Place Economist, 23(1), 11.

Dappa, T., \& Daminabo, D. (2011). Deregulation of the Nigerian economy: The theoretical milieu. In 1st International Technology, Education and Environment Conference.

Dauda, R. S. (2017). Poverty and economic growth in Nigeria: Issues and policies. Journal of Poverty, 21(1), 61-79.

Dauda, S. (2019). The Paradox of Persistent poverty Amid High Growth: The Case of Nigeria. Immiserizing growth: When growth fails the poor, 250.

Deaton, A. (2005). Measuring poverty in a growing world (or measuring growth in a poor world). Review of Economics and statistics, 87(1), 1-19.

Ebinumo, S., \& Ikunga, S. A. (2019). The Dynamics of Foreign Aid and The Dependency Theory: The Nigeria's Experience. KIU Journal of Humanities, 4(2), 87-94.

Eme, O. I., \& Onwuka, C. C. (2011). Political economy of deregulation policy in Nigeria: the challenges ahead. Journal of business and organizational development, 2(1): 1-21.

Ezekwesili, O. (2013). The wealth and poverty of a nation: who will restore the dignity of Nigeria. Keynote paper delivered at 42nd Convocation of University of Nigeria, Nsukka, Thursday 25th February.

Federal Ministry of Power. (2014). Annual report of the Ministry of Power. Abuja.

Galtung, J. (1971). A structural theory of imperialism. Journal of peace research, 8(2), 81-117.

Gbosi, A. N. (1997). Chronic unemployment in Nigeria. International Journal of Employment Studies, 5(1), 155.

Gilpin, R. (2016). The political economy of international relations. Princeton University Press.

Holmes, P. (1985). Nigeria: giant of Africa. National Oil and Chemical Marketing Co. of Nigeria.

Hoselitz, B. F. (1960). Sociological aspect of economic growth. New York: Free Press.

Ibe, S. (2010). Implementing economic, social and cultural rights in Nigeria: Challenges and opportunities. African Human Rights Law Journal, 10(1), 197-211. 
INTERNATIONAL JOURNAL OF ACADEMIC RESEARCH IN BUSINESS AND SOCIAL SCIENCES

Vol. 10, No. 6, June, 2020, E-ISSN: 2222-6990 @ 2020 HRMARS

Igwe, S. C., Abdullah, M. A. I. L., \& Sherko, K. (2016). Impact of external debt-induced structural adjustment policies on salient aspects of the Nigerian economy. Canadian Social Science, 12(12), 42-47.

Ikejiani-Clark, M. (2008). Nigerian government and politics. Lecture notes, Department of Political Science, University of Nigeria, Nsukka.

International Labour Organization. (1982). Resolution concerning statistics of the economically active population, employment, unemployment and underemployment. Adopted by the 13th International Conference of Labour Statisticians, Geneva, 18-29 October.

Transparency International. (2017). Corruption perceptions index 2017.

Kalejaiye, P. O., Adebayo, K., \& Lawal, O. (2013). Deregulation and privatization in Nigeria: The advantages and disadvantages so far. African Journal of Business Management, 7(25), 2403.

Kuye, O. (2012). The economics of deregulation and ramifications for law and development. Economics, 3(4).

National Bureau of Statistics. (2011). Statistical news: Labour force statistics. Abuja: The NBS Publication.

National Bureau of Statistics. (2014). Statistical news: Labour force statistics. Abuja: The NBS Publication.

National Economic Empowerment and Development Strategy (2003). Nigeria: National Economic Empowerment and Development Strategy. Abuja. National. Plan. Comm.

Ndukwe, E. (2005). Telecom liberalization in Nigeria: Opening up the market and sector reform. In Proceedings of the SATCOM 2005 Conference.

Nnamani K (2003). Making Nigeria work: My mission as a senator. Abuja: Yaliam Press.

Nnoli, O. (1981). Development/underdevelopment: is Nigeria developing? Path to Nigerian Development. CODERSIA, Senegal.

Nwokocha, E. E. (2009). Deconstructing the burden of rural-urban migration in a non-regulatory system: the case of Lagos, Nigeria.

Obadan, MI. (2014). A critical appraisal of the Nigerian economy 54 years after independence. Retrieved from $h t t p: / /$ theeconomyng.com/?p=559

Oduwole, T. A. (2015). Youth unemployment and poverty in Nigeria. International Journal of Sociology and Anthropology Research, 1(2), 23-39.

Offiong, D. A. (1980). Imperialism and dependency, obstacles to African development, Enugu. FourthDimension Publishers.

Ojo, C. R. (2010). Adult Education in a Deregulated Economy: A case study of Nigeria. Retrieved on August, 6, 2015.

Okolie, A. M. (2005). Re-engineering African development through the NEPAD strategy: A study in dependency. African Journal of Political and Administrative Studies (AJPAS), 2(1), 15-32.

Okolie, A. M. (2015). Global political economy and development of underdevelopment: Different people, same market and glorification of poverty.

Okonkwo, C. E. (2014). National economic empowerment development strategies (Needs) and labour in Nigeria, 2003-2007. Journal of Good Governance and Sustainable Development in Africa, 2(2), 152-161.

Olabisi, J., Afolabi, A., Kajola, S. O., \& Ariyibi, O. (2019). Effect of Currency Depreciation on Financial Performance of Nigerian Deposit Money Banks. Izvestiya, (2), 104-116.

Olashore, O. (1999). The Challenges of Nigeria and Economic Reforms Ibadan. 
INTERNATIONAL JOURNAL OF ACADEMIC RESEARCH IN BUSINESS AND SOCIAL SCIENCES

Vol. 10, No. 6, June, 2020, E-ISSN: 2222-6990 @ 2020 HRMARS

Onimode, B. (1982). Imperialism and underdevelopment in Nigeria: the dialectics of mass poverty. Zed Books.

El-Tom, O. A. (1994). Mugging the poor: the Bretton Woods institutions and the pursuit of African development; an IFAA contribution to the 50th anniversary of the Bretton Woods institutions.

Ovaga, O. H. (2010). Deregulation of downstream oil sector in Nigeria: its prospect. Journal of Social Sciences and Public Policy, 2(1), 16-27.

Owojori, A. A. (2011). The effect of the emerging economic policies on investment in Nigeria. Journal of Emerging Trends in Economics and Management Sciences, 2(3), 206-214.

Pettman, J. J. (1996). An international political economy of sex. Worlding Women: Towards a Feminist International Politics. New York: Columbia University Press

Rodney, W. (1972). How Europe Underdeveloped Africa, Harare. Zimbabwe Publishing House.

Rostow, W. W. (1960). The stages of growth: A non-communist manifesto (pp. 4-16). Cambridge: Cambridge University Press.

Statistical, E. (2007). SOCIAL RESEARCH AND TRAINING CENTER FOR ISLAMIC COUNTRIES (SESRTCIC). 2007. Poverty in sub-Saharan Africa: The situation in the OIC member countries.

Ukpe, P. O., \& Omeonyekwule, V. M. (2019). The Challenges of Inter-Governmental Relations in Nigerian Federalism. International Journal of Governance and Development, 6(1), 51-58.

Winston, C. (1993). Economic deregulation: Days of reckoning for microeconomists. Journal of economic literature, 31(3), 1263-1289. 